\title{
CF-1 Mouse
}

National Cancer Institute

\section{Source}

National Cancer Institute. CF-1 Mouse. NCI Thesaurus. Code C77116.

Thought to be wild albino in origin, this strain was obtained by Carworth farms from a Missouri laboratory. It was intensely inbred by N. Goto in 1978 from a single Carworth pair, the progeny of which is used today. The CF-1 mouse has an albino coat with genotype $c$ and is used as a multi-purpose strain for a variety of applications including infectious disease modeling, embryological studies, and safety and efficacy testing. In this mouse model, cleft palate formation can be induced by cortisone while alloxan treatment induces diabetes in a high percentage of CF-1 mice. 